\title{
PRODUCING INNOVATIONS: A LOW-KEY SCIENCE POLICY ON EMBRYONIC STEM CELLS
}

\author{
Philippe Brunet
}

De Boeck Supérieur | «Journal of Innovation Economics \& Management »

$2017 / 1 n^{\circ} 22$ | pages 9 à 27

ISBN 9782807391116

Article disponible en ligne à l'adresse :

http://www.cairn.info/revue-journal-of-innovation-economics-2017-1-page-9.htm

\section{Pour citer cet article :}

Philippe Brunet, « Producing Innovations: A Low-Key Science Policy on Embryonic Stem Cells », Journal of Innovation Economics \& Management 2017/1 ( $\left.\mathrm{n}^{\circ} 22\right)$, p. 9-27.

DOI 10.3917/jie.pr1.0003

Distribution électronique Cairn.info pour De Boeck Supérieur.

(C) De Boeck Supérieur. Tous droits réservés pour tous pays.

La reproduction ou représentation de cet article, notamment par photocopie, n'est autorisée que dans les limites des conditions générales d'utilisation du site ou, le cas échéant, des conditions générales de la licence souscrite par votre établissement. Toute autre reproduction ou représentation, en tout ou partie, sous quelque forme et de quelque manière que ce soit, est interdite sauf accord préalable et écrit de l'éditeur, en dehors des cas prévus par la législation en vigueur en France. Il est précisé que son stockage dans une base de données est également interdit. 


\title{
PRODUCING INNOVATIONS: A LOW-KEY SCIENCE POLICY ON EMBRYONIC STEM CELLS
}

\author{
Philippe BRUNET \\ Science Innovations Society Interdisciplinary Laboratory \\ University of Paris-Est Marne La Vallée \\ INRA, CNRS, ESIEE, France \\ Philippe.brunet@u-pem.fr
}

\begin{abstract}
Human embryonic stem cells (hESC) are the subject of research that requires destroying the embryo. The result is a tension between the logic of development of innovations and ethical constraints. This article seeks to understand this dynamic of innovation and its non-availability in France, focusing on political science. After understanding the development model of innovation and the concept of political science, the analysis focuses on the establishment of a normative ethical barrier against research on hESCs. This establishes a principle 'prohibited with derogation to be seen', full of ambiguity. The tension generated by this principle led the State to implement a low-key policy: limited, hidden and delegated. Faced with this tension, scientists are trying to develop workarounds, both politically and at scientific level, to continue the innovative dynamic.
\end{abstract}

Keywords: Human Embryonic Stem Cells, Low-Key Science Policy, Innovative Dynamics, Normative Ethical Barrier, State, ISTEM, AFM

JEL Codes: 038, 030

Human embryonic stem cells (hESCs) have been highlighted, in the form of lines, by an American biologist (Thomson, 1998). Since then they have been the subject of research that is as developmentalist as it is therapeutic at a global level ${ }^{1}$. However, the need to destroy the embryo to produce these is an obstacle to the dynamics of innovation, in terms of their potential uses and clarification of their status. Thus these cells, identified and

1. The interest of trials on hESC lines derives from their potential for pluripotency and selfrenewal. Through their non-differentiation, they can produce all the cell types of the human body. Through their ability to endlessly self-renew it is possible to produce them in very large amounts. 
calibrated thanks to authorised trials, have become potential objects of innovation, with a special status for innovations. Characterising them in this way assumes two hypotheses. First, they are reversible from the viewpoint of the ends and means that they represent (Dewey, 2011), in that they are provided with a dual status of object and quasi-subject. Next, the experimental work which transforms them transcends the enclave of the laboratory; even if it originates there and remains there as a location for a litmus test. This is aimed at techno-scientific production legitimised by an orb, one of the master-symbols of which is the word innovation (Wright Mills, 1967). This dual characterisation results in a significant tension, which acts on the innovation dynamic of these cells. In fact, although the developmental logics of techno-scientific innovations respond to structural effects, in this case these are constrained by the rigidity of an ethiconormative barrier.

By analysing science policy, this article will try to understand the dynamics of innovation of hESCs in France which results from this ${ }^{2}$. As innovations are always projected towards the future, we will approach this science policy as a power of influence, operating from measures to frame and evaluate actions to come concerning techno-scientific innovations, which the actors concerned produce and to which they react. To understand this dynamic, we will first justify the relevance of establishing a model that is relatively stabilised, as this structure is not without some evolution in terms of the influence of science policy (Rouban, 1990). After that, the tensions that are specific to science policy for hESCs can be addressed. Thus in a second phase the analysis will deal with the controversial establishment of an ethico-normative barrier which sets limits to this research and to its innovations around an ambiguous principle: prohibition with derogations to be seen. In a third phase, its consequences will be explored, leading to a description of this science policy as low-key. Contested by scientists in particular, we will finally show how these sought to circumvent this barrier to continue the innovation dynamic of this research, contributing to its development.

The analysis is mainly based on data from an intensive investigation that was conducted at the largest laboratory in France for research on hESCs (observations, over a hundred interviews, various documents and archives) from 2005 to 2007 (Brunet, 2008), then more flexibly until 2012.

2. A rigorous international comparison would merit a dedicated study which, to our knowledge, does not exist. Nevertheless, we will not refrain from mentioning a few examples. 


\section{SIS MODEL AND SCIENCE POLICY ON TECHNO-SCIENTIFIC INNOVATION DYNAMICS}

From the beginning of the 19th century, as in other European States, France has supported the development of industrial innovations, promoting ad hoc legislation (Lascoumes, 1989). The modern figures of the scientist, the entrepreneur and the politician, sometimes conflated in the same person, produced a new kind of national development, based on the intensive production of goods (Fressoz, 2012). This was based on three pillars: science, industry and the national State. It became the SIS model for the boom in the capitalist economy and remains so today, even if its development is observed in different configurations (Stengers, 2008). For example, after the Second World War the combined effect of militarisation and the increase in dead capital in science led advanced western States to promote scientific policies to develop industry in some areas. The Bush report (1945) developed this model by confirming the principle of autonomous science supported by the State, an institution vital for industrial development and for market growth. In this configuration, bolstered by powerful mechanisation, science became techno-science, i.e. operative (Hottois, 1996). Since then, the State, science and industry have not ceased to be the required structure of productive growth. The controversies to establish the truth of the existence of modes 1 and 2 of science and their succession (Gibbons et al., 1994; Pestre, 1997) change nothing of the structure of the SIS model, which takes on different tones, depending on the discipline, their capacity to convert their results into merchandise, and the national policies to help them with this. Today it is deployed in a more or less standardised way on a global scale in the form of clusterisation (Forest, Hamdouch, 2009) and follows the movement of the financialisation of capital, without, however, being uniform. Thus, even with globalisation, national frameworks continue to impact innovation processes (Joly, 2016). Consequently, the influence of politics at the national level invites us to clarify the concept of science policy.

To avoid any risk of confusion between the slogan that it conveys, and its more qualified reality, some analyses suggest being cautious about this concept (Jacq, 2002). For his part, explaining the concept of public policy as applied to science, Rouban proposes that it should be understood as "an area of social relations which partly connects the political market to the market for economic goods" (1990, p. 80). This approach involves an extensive and hierarchical vision of these relations, loosely linked to production. In part, this viewpoint is in accordance with the SIS model. In fact, regarding the analysis of public policy on science, by setting as a reference the effectiveness 
of these social relations, Rouban analyses the substitution, in political discourse, of the concept of public policy on science with that of public policy on innovation, revealing a more explicit aim of scientific production. This is contemporaneous with the more confirmed presence of biology, strengthened by its molecularisation and the introduction of a mechanisation which speeds up the dynamics of innovation. So from the 1980s, American universities established more links with businesses outside the power of the federal State (Rouban, 1990). This phenomenon was expanded at variable speeds and in national configurations (Gaudillière and Joly, 2006). This Science business, strengthened by biotechnological Big Science, had repercussions at the industrial and professional level, for example weakening "age-old professional rights (free communication of work, sharing results, selflessness)" (Rouban, 1990, p. 93).

To this rapprochement between science and industry must be added changes in the relationship between the State, via public policy which supported the commercialisation of the results of life sciences, of which the Bayh-Dole Act in the USA is one expression, and some sectors of society who are opposed to this. The institutionalisation of ethics illustrates these changes. It contributed to expanding the field of these different, connected, social relations, and making them denser. In fact, if bioethics was established as a response to the power of medicine that was being industrialised (Bateman Novaes, 1998), it also appears to be a defence against commodification (Sève, 2006). Consequently, there is a contradiction at the heart of policy. On the one hand, the State seeks to encourage the deployment of innovations by promoting links between science and industry, as the market is the only measure of their success; on the other, in a subordinate manner (Cassier, 2002), it puts in place mechanisms that are supposed, through an ethical imperative, to subject the direction of this innovation dynamic to values that conflict with this (Pulman, 2005).

Subsequently, the responses made in science policy are ambiguous. For example, regarding hESCs in the United States, in 2001 President Bush decided, in the name of respect for life, only to grant federal credits to research on existing cell lines, prohibiting new ones from being created (Lepinay, 2006). But in the name of respect for the market and the right American States have to support science, he was not opposed to their creation if this was funded outside the federal budget. In another form, this situation structured research on hESCs and their innovation dynamic in France. Therefore, you have to think through the implications of what is stated as a consequence. Indeed, for Rouban, the concept of science policy replaced that of public policy on science (1990). Should we understand that all science policy that is directed towards innovation and commodification 
is no longer confined only to State action, and that other actors in practice contribute to this? In this case, considering not so much the very relative reduction in the role of the State in supporting the dynamics of production through science (Uzunidis, 2003) as its repositioning, the concept of science policy, examined from the viewpoint of plurality, helps us to see this more clearly and, paradoxically, strengthens the robustness of the SIS model. In fact, we venture that this plurality, in a given field, expresses the aggregation of issues and commitments, sometimes in competition, which concern techno-scientific innovations and which the State has to take into account. This policy results in contrary concerns for the hESC sector. These require the State to build an ethico-normative barrier which produces its own constraints.

\section{FRAMEWORK AROUND A PROHIBITION ON RESEARCH WITH DEROGATIONS TO BE SEEN}

The Bioethics Act, approved in July 2004, was the result of a process which involved several biomedical techniques, both from the viewpoint of their acceptability and their practices. It is the result of a revision of an initial law approved in 1994. Research on the embryo and on hESCs, where the former was banned, not to mention the latter, was the subject of the fiercest controversies. The government of the Left, which supported this revision from 2001, encouraged this research. In January 2002 a "minor law" was approved, which authorised this under supervision ${ }^{3}$. This text provided that research projects would be subject to the opinion of a regulatory authority, the Human Reproduction, Embryology and Human Genetics Agency (APEGH) which, after an assessment, would grant authorisations. Its legislative process was then interrupted by the Presidential and legislative elections, which resulted in a majority for the Right. In July 2004 the final law was approved. Overturning the principle of authorisation endorsed two years before, it prohibited research by allowing derogations. We examined the process of this controversy between 2001 and 2004 from parliamentary debates. It ended with the enactment of a new restrictive principle, prohibition of research with derogations to be seen to see, provided with a particular mode of implementation.

3. A "minor law" is a text approved in the first reading in the National Assembly. Most MPs on the right voted for or abstained. 


\section{Authorisation under Supervision Overturned by Prohibition with Derogations to be seen}

The status given to hESCs and the innovations which could result from this, especially therapeutic cloning (Fagot-Largeault, 2004), are at the heart of the dispute: object or quasi-subject? However, scientists made efforts to assert that hESC lines, obtained by tests on embryos destined for destruction, are not an insurmountable ethical problem ${ }^{4}$. Apart from a cognitive benefit, a therapeutic benefit is expected from this. The opposing argument asserted that this destruction, like the biomedical technique which creates these embryos, contravenes the principle of human dignity.

A year after the minor law was approved, the significance of the situation was linked to its reversal. The argument which, until then, aimed to separate hESC lines from the embryo was overturned in favour of a consubstantial link. From being precious objects they became, like the embryo, quasi-subjects. The report of the Senate's Social Affairs committee pointed out the problem: "The question of the embryo is undoubtedly the most difficult point addressed by the draft bill: it was so in 1994, it remains so today" (Giraud Report, p. 10) ${ }^{5}$. The solution appeared to be consistent: the ban was nonnegotiable. But its weakness appeared when it was planned to derogate from the ban to conduct research with a view to innovations:

"However, can one and should one for ever close a door to research without knowing anything about its potential and its safety? In 2003 the legislator should retain the same moderation as in 1994 and itself recognise the possibility of a derogation that is temporary and strictly framed in the basic principles that it has provided, by allowing research to be conducted only on embryos that are no longer the subject of parental agreement, after agreement by members of the couple [...]" (Giraud Report, 1993, pp. 10-11).

The derogation from the ban on research on the embryo in the 1994 Law was consistent. The condition was not to harm the life of the embryo. But access to hESCs involved its destruction. Opposed to the principle of authorisation, nevertheless the Senate adopted a similar policy by promoting the ban with derogations. But it introduced an inconsistency: on the one hand, the ban was based on the principle of respect for human life; on the other, the derogation concerned the use of hESC lines created from

4. The scientists' argument is to say that embryos already exist prior to any research. They were created for Assisted Reproductive Technology (ART) and are no longer the subject of a parental project.

5. Senate, 2003, Report $n^{\circ} 128$, done on behalf of the Social Affairs Committee on the bill adopted by the National Assembly on Bioethics, by Francis Giraud, 15 January, 477 p. 
destroyed supernumerary embryos. How did the senators try to make something consistent that wasn't consistent?

Two arguments were put forward. One defended the derogation for promising therapeutic reasons. Harm to life could be allowed if this was targeting a greater benefit. With this perspective, the innovation dynamic was not halted. However, by imposing a time constraint on research, the second argument limited the scope of the first: limited to five years the derogation should be enough to know and evaluate the therapeutic potential of hESCs better.

This proposal is similar to a bet on the results of science. It follows from an implicit negotiation between the State and scientists and expresses a contradiction that it tries to resolve: on the one hand, it is about keeping to the ban in the name of the quasi-subject status of hESCs and respecting this; on the other of exploring, even so, and for a period of time, the potential of hESCs as an object. hESCs temporarily became potential objects of innovation with a view to therapeutic innovations. The form taken by the proposal was included in a ban with derogations, namely to know how far exploring hESCs could lead, subject to a comparison, to an innovative aim, with the potential of CSAs. This test of experimental submission aimed to re-establish an abused ethical consistency. In December 2003, the debate started again in the National Assembly on this basis. The law, approved in summer 2004, established this new principle of a ban with derogations ${ }^{6}$. Its application implied a new framework.

\section{How to Derogate from the Ban?}

Evaluation is one of the problems posed by derogation. The "minor law" of January 2002 created the APEGH. Its mission is to authorise research procedures:

"Research can only be undertaken if its procedure has been subject to authorisation by the Human Reproduction, Embryology and Human Genetic Agency. The decision to authorise is taken according to the scientific relevance of the research project, its conditions of application with regard to ethical principles, and its interest for public health. ${ }^{7}$

So the APEGH had to make both a biomedical scientific evaluation and an ethical evaluation. In this respect, the agency had a High Council, a body for a future evaluation mechanism, comprising representatives of political

6. J.O n 182 of 7 August 2004 page 14040. Law n² 2004-800 of 6 August 2004 on bioethics.

7. Ibid, cf. Art. L. 2151-3. 
and judicial institutions and other members with different expertise. This has become the condition for politics: make decisions by relying on scientific expertise (Granjou, 2003). This expertise was shared out between institutional expertise and the established expertise of the associations (Brunet, 2006). To this was added ethical expertise, with two members. This expert capability, representing half the High Council, was made up of two thirds scientists and one third non-specialists.

In its reform of the bill, the Senate proposed changing the APEGH. The formulation of the High Council was criticised for having too limited a capacity for scientific expertise. The Senate opted for a medical and scientific Advisory Board (AB), marking the presence of established expertise more clearly. Moreover, the senators agreed with the arguments of the Minister of Health, who planned to merge the APEGH and the French Blood Service (EFG) with the Biomedicine Agency. Characteristically, this was about responding to the inflation in "second rank bureaucracies", which complicated public administration management (Benamouzig and Besançon, 2005).

During the parliamentary debates the plan was amended. The law did indeed create the Biomedicine Agency (BM) and the AB replaced the High Council. But its make-up was only slightly changed. In the end, thirty one members had to provide multiple expertises (scientific, social and ethical) on research projects that required their authorisation.

\section{RESEARCH ON hESCs: WHAT KIND OF SCIENCE POLICY?}

To a certain extent, this ethico-normative barrier created a new situation. Research on hESCs, although promising, was banned, as derogations were possible. This was counter to the dominant discourse and practices of innovation. The respect owed to human dignity mattered more than any biomedical innovation and any business that would result from this, unless it was described as major at the therapeutic level. The value of the ban was therefore not absolute. Accepting its transgression amounted to making a convincing therapeutic prospect at least equivalent to its cost in terms of benefits. This seemed to be the clause prior to being realised. This situation was not limited to France but it stood out in terms of its form.

In fact, the governments concerned by this research were all forced to define a legal framework. They opted for different solutions, from the greatest permissiveness to the most complete ban (Ott, 2007). This variability 
led to irritation amongst scientists and "innovators". They considered that it created distortions in the knowledge market at the cost of scientific progress. It caused confusion, which was expressed by the often-expressed invocation that France was lagging behind (Bouchard, 2008): "A bioethical law was applied which paralysed us. So we lost ten years. Really. I'll say it. We lost ten years in this field! And it was difficult to recover." (Interview, biologist, CNRS)

Whatever the dversity of national legislation, this barrier partly determined the future of research on hESCs in France. In this context, one could ask if there is a policy for this research? If this is the case, what form does it take? In what conditions is it conducted? How do scientists understand it? In fact, this policy does exist. But, limited, dispersed and not very visible, it is low-key.

\section{A Low-Key Science Policy}

Two criteria for the existence of a science policy can be identified: its funding and how it is made public. Certifying that such a policy exists in a particular field is to show how and to what extent this field is funded. But concerning the hESC sector, when the law was adopted in 2004, the Government had to manage this contradiction: can you promote research that was previously disqualified by ruling that this is transgressive?

Earlier, in April 2000, Roger-Gérard Schwartzenberg, then Research Minister, put in place a joint action between his ministry, INSERM and AFM to promote research on CSAs as an area of stem cells. The following year this measure was integrated into the Incentivising Combined Action (ICA) "biology of integrative development and physiology". At the same time, from 1999, INSERM launched Combined Thematic Action (CTA) on biotherapies, where the subject of stem cells had priority. The objective aimed both to fund research on CSAs and to strengthen a community of researchers that was considered to be too divided.

This priority given to research on stem cells was not surprising. On the one hand, facing the impossibility of carrying out research on hESCs, only CSAs were explored; on the other, the interest in these also originated in a scientific controversy. It concerned the assumed but not proven capacity for the transdifferentiation of CSAs, understood as the power to despecialise (dedifferentiation) and to convert their functionality into another kind of specialised cell. The controversy expressed the scientific challenge of cell plasticity, still little known. But it also went beyond the frontiers of science. It fed the idea that, in the case of the proven transdifferentiation of CSAs, research on hESCs could be avoided. The obligation to compare the 
respective potential of CSAs and hESCs, a condition for the derogation principle, here found its raison d'être. Essentially, the scientific interest of hESCs resonates politically with the issue of development or, conversely, stopping the innovation dynamic in this field, and it persists ${ }^{8}$.

The political conditions imposed on hESCs do not allow research to be supported in a clear way. Since 2004, this constraint has had its expression: no invitation to tender coming from the Ministry of Research, the ANR or INSERM, any more than any incentivising measure, has mentioned funding research on hESCs: "There's never been any. Not on hESCs. [...] OK, before 2004 it was impossible. And even afterwards there was always a lot of timid$i t y$... So there has never been, specifically, any programme on hESCs" (Interview, administrative manager, Ministry of Research).

But without financial resources science is incapable of functioning. Consequently, some funding has been mobilised for research on hESCs without being clearly identified. Generally, this concerns investment for instrumentation or personnel expenditure, contributed by INSERM, the AFM, regional authorities or universities. Funding through tenders is mobilised when hESC projects are linked to broader issues which concern stem cells or pathologies ${ }^{9}$. A science policy for hESCs is taking shape, more or less hidden, where INSERM plays a role of delegator for the State, as do some universities as well:

"People have seized on this tool to make it a kind of standard-bearer for the institutions. In other words, the university wanted to have its lab for embryo stem cells [...] I think that this aspect of things shouldn't be neglected either, because there has effectively been a certain windfall to launch this. Even if it is true that in fact there has never been any large national project on embryo stem cells, as there has been elsewhere." (Interview, biologist, INSERM)

8. In an opinion entitled "Invisible France", published by Le Monde on 20 June 2008, Philippe Menasché, a biologist and a doctor specialising in cardiac pathology, wrote: "[...] The Bioethics Law should be revised in 2009 at the end of the forum. Today there is a real fear that this deadline will be postponed because of a government timidity that is all the more frustrating as France has some major assets, scientific (quality of teams), medical (recognised expertise in clinical research) and institutional (efficiency of the French Agency for the Safety of Health Products and the Biomedicine Agency), which are still undervalued. This situation is due to the complexity of the current law, and in particular its nature in terms of derogations, which could be understood in the context of 2004, but which is no longer topical. This restrictive nature makes France's position unreadable by other countries, demotivates teams whose basic research is long-term, dissuades our young postdoctoral students who are interested in this subject from returning from abroad, and discourages venture capitalists from investing in our country. [...]"

9. For example, the Ingecell mechanism of the Medicen innovation centre, centred on molecular and cellular medicine, concerns all cellular forms but includes research of which most is concerned with hESCs. 
Likewise, with "project leaders", and in partnership with other institutions, INSERM has put in place mechanisms called technical support, which includes research on hESCs. This is the case with the ISTEM project, led by Mr. Peschanski in partnership with the AFM, and that of A.-L. Bennaceur at the University of Paris XI. In February 2006, the Inserm-Actualités newsletter contained an article entitled: "Stem cells: Inserm with a ringside seat". It described this policy that had been delegated to INSERM. The emphasis was placed on the dynamics of innovation. hESCs figured prominently:

"Our country should now focus its efforts in RED on: 1) Increasing exploration of the therapeutic potential of human embryonic stem cells at the national level. - Supporting the emergence of centres of reference for research on embryonic stem cells, such as ISTEM, IRB in Montpellier and the Villejuif centre. - Providing a central technical and logistical service for France which will supply prepared cells (proliferation - sufficient number) to research teams. - Inclusion in activities to create international cell banks. 2) Promoting the development of clinical trials in the field of cell therapy [...]" (Inserm-Actualités, p. 4).

However, in this edition INSERM's "stem cell" invitations to tender do not contain any mention of research on hESCs. This science policy, delegated by the State, responded to the demands of some scientists, project leaders, who wanted to achieve their strategy, and for INSERM to support this. Finally, a certain similarity can be detected with the period of the Bush presidency in the United States. Like this, it refused to legitimise a research policy on hESCs at government level, while allowing some institutions to plan for this by allocating resources ${ }^{10}$.

\section{Arrival on the Scene of Research on hESCs}

We can have a fair idea of what this policy has produced. Indeed the number, identity and the chronology of research protocols on licensed or nonlicensed hESCs are known. ABM keeps track of this. 73 protocols have been

10. According to J. Y. Nau (Le Monde of 30 July 2006), the hypocrisy of the Bush administration has resonances in Europe. Solutions are found to try to minimise the impact of the European ethico-normative barrier: "[...] Thus, on 24 July, the European Union approved Community funding for some research on human embyronic stem cells as part of the $7^{\text {th }}$ Research and Development Framework Programme, with a total of 50.4 billion euros for the period 2007-2013. But, contrary to the vote in the first reading of the European Parliament in mid-June, this funding may only concern work that does not involve the destruction of human embryos. In other words, only stem cell lines that currently exist - and which are obtained at the cost of the destruction of embryos from which they have come - can be the subject of research that receives Community funding. [...]" 
authorised over ten years, up to autumn 2014. These involved 32 laboratories, most of which hosted INSERM teams. Four private firms completed this overview.

Their geographical distribution seems to partly overlap with the map of laboratories which have worked on CSAs. The hypothesis should be expressed with caution. Research on hESCs has also helped to redistribute scientific teams. Some dense points have thus appeared (Brunet and Dubois, 2012). The densest is the ISTEM laboratory of Mr Peschanski in Evry, which holds about a quarter of licences in France. A.-L. Bennaceur's laboratory in Villejuif has 7 protocols. This leads to two observations.

On the one hand, these two heavyweights hold a third of the licences issued. These are also the ones for which INSERM has raised specific resources. On the other hand, created ex nihilo with the help of the 2004 law, ISTEM is typical of the extension of the field of stem cells to research on hESCs and the opportunities to which this leads. Its plan is to produce repair cells for cellular therapies and human cellular models to test new pharmacological molecules within the framework of monogenetic diseases.

Taking account of data from ABM, it is useless to seek a causal relationship between the existence of the ethico-normative barrier and the number of protocols licensed. Nevertheless, over ten years four refusals have been notified, representing a low proportion of demands. Furthermore, an investigation at ABM shows that it has helped to support projects. An evaluation system negotiated with scientists was set up to help with this task. This is similar to a mechanism to offer protection against politics, which builds on relations of trust arising from the procedural framework. This process suggests both auto-selection of applicants and a reciprocal integration between two worlds. Thus, the licensing procedure, irrespective of the principle in force ${ }^{11}$, involves a certain level of competence and organisation by scientists. In return, it assumes scientific and management credibility by ABM which, until then, had never been tested.

Paradoxically, low-key science policy concerning research on hESCs, although developed in a limited and dispersed manner, resulted in producing points of density. To succeed, this policy should have been supported by sectors other than the State. This is the case with the ISTEM laboratory, which could not have been established without the support of AFM.

11. Following the 2004 law and its revision in 2011, a vote in Parliament in July 2013 replaced the principle of prohibition with that of licensing. Although this satisfies scientists, it changes nothing of the procedure. 


\section{The AFM and hESCs: Asserting a Political Will}

The commitment of patients associations to research makes a contribution to science policy. On average, patients associations raise $42 \%$ of their budget for research (Rabeharisoa, Callon, 2002). So we can talk about a research policy to describe their commitment to science (Larédo, Kahane, 1998). In these conditions, the match between the AFM and hESCs is not fortuitous.

The scientific history of AFM shows its overriding interest in gene therapy (Barral and Paterson, 1994). With this in mind, AFM has adapted to the system of tendering, while deploying permanent scientific teams in its laboratories, which allow it to develop therapeutic innovations. AFM's strategy seeks to reconcile patients, clinics and research, as this is considered to be a required digression to satisfy the therapeutic aim (Callon and Rabeharisoa, 1999). This configuration guides the strategy of the associations. Consequently, the issues raised by stem cells have also attracted the vigilance of the associations.

Beyond gene therapies, the AFM's scientific supervision demonstrated its interest in new possibilities. In December 2001, the AFM's scientific director published a note on hESCs. It mentioned the publication in September, by the American J. A. Thomson, of results on the subject of "the possibility of obtaining haematopoietic cells from human embryonic stem cells". The note emphasised that "certainly a first step has been made towards cellular therapy for degenerative diseases" ${ }^{12}$. This research was seized on as a new opportunity. The financial strength of the AFM allows it to invest when INSERM only has limited resources to offer. This is the case with the research project led by Mr. Peschanski on hESCs: "INSERM doesn't want to fight against the financial resources of AFM. They have real resources. If they want to employ staff they can take them on, they deploy staff. AFM is a real heavyweight. It's essential that they're involved in this field, that's clear!" (Interview, INSERM manager)

At the same time, the association sought to determine the ethical challenge in this opportunity. In June 2002, it took the initiative to debate research on hESCs and therapeutic cloning with its members. Using the model of a consensus conference, the association organised a debate entitled "Stem cells and therapeutic cloning: experts against patients". This was about an ethical legitimisation of its position concerning the use of hESCs and the feasibility of therapeutic cloning. There was no surprise about the opinion: it confirmed the need to license this research for a therapeutic purpose. This was a mandate that was expressed. For the AFM, this research is a

12. AFM, Information scientifiques, $n^{\circ} 47$, December 2001. 
strong point of its policy. It has funded about $50 \%$ of the ISTEM laboratory for more than ten years. Consequently, although it has found its approach in France through the convergence of the State, which delegates a low-key science policy and the clear wishes of actors like the AFM, nevertheless all science policy on hESCs remains subject to the constraints created by the ethico-normative barrier. This is why scientists have tried to counter this or outflank it.

\section{SCIENTISTS FACED WITH THE CONSTRAINT OF THE ETHICO-NORMATIVE BARRIER}

In this last point, we examined certain situations which present all the different reactions by scientists to this constraint. In fine, the inventiveness of scientific expertise appears to be the most certain way of circumventing this.

\section{Prevented Research and Innovations: The Influence of the Political-Legal Sphere}

Two different situations which scientists have been confronted with merit an analysis. The first is connected to access to cellular material and research work; the second to the production of marketable innovations.

\section{Forcing Access to hESCs Lines}

In autumn 2001 Jacques Hatzfeld, a stem cell biologist, took the initiative with a petition addressed to the Minister of Research. It demanded the start of research on hESCs without destroying embryos, since lines are available abroad. Signed by four Nobel prizewinners and more than 500 scientists, the petition was handed to the Minister in November. He declared that he supported the initiative. In fact, it supported his bill. At the same time, Hatzfeld officially requested a licence to import two lines of hESCs from Australia. Consequently, the ministerial bureaucracy sought a regulatory and political solution. The regulatory aspect was found in the decree of 23 February 2000 on the law of July 1998 relating to strengthening the health supervision and health monitoring of products intended for humans. As available lines, this decree made them legally equivalent to any other cellular material. The political aspect took an experimental turn: the application should comply with the spirit of the bill. As in a mirror effect, the Minister appointed a Committee of Wise Men charged with evaluating the application scientifically and ethically. This anticipated the High Council of the future APEGH. After approval of the minor law, which 
gave additional legitimacy to the approach, and the positive opinion of the Committee, the Minister authorised the import before having to leave the Government.

After the announcement of the licence, several import requests were filed. But, given the new government situation, scientists were henceforth dissuaded by ministerial departments. Hatzfeld became the only scientist in France working on hESC lines. Moreover, in this situation, the licensing was attacked legally by the association, the Alliance for the Rights of Life. This asked the administrative court to annul the decision on the grounds of excessive power and to suspend its enactment through an emergency interim ruling. Finally, in May 2005, the Administrative Court of Appeal confirmed the legal legitimacy of the decision taken four years earlier.

But, in the meantime, several unexpected developments punctuated this legal process, demonstrating the difficulties in ruling on hESC lines. Because the question remains: what link can be made between these lines and the embryo? An object or a quasi-subject? The association's interim application was dismissed by the administrative court in June 2002. It lodged an appeal to the Council of State which, in November, adjourned the decision for four months pending a ruling on the background. This adjournment had an effect: the first research on hESCs in France was halted at that time.

\section{The Brüstle Affair or the Story of a Banned Patent}

Olivier Brüstle is a German biologist, an expert on neurological diseases. He holds a patent on neural cells that he produced for therapeutic purposes from lines of hESCs. Its legitimacy was attacked by Greenpeace before the German Patent Court. This noted its invalidity on the grounds that these cells came from the embryo. Brüstle then appealed to the German Federal Court of Justice, which took action before the European Court of Justice. In October 2011, based on European Directive n ${ }^{\circ}$ 98/44/CE, which excludes the patentability of the human body, the Court confirmed the invalidity of the patent for an invention which requires the prior destruction of embryos.

There were many reactions by scientists to this decision. The impossibility of producing marketable innovations seemed to be an economic and political defeat. The newspaper Le Monde published the reaction of Marc Peschanski, who: "was worried about the consequences which will mainly affect innovative biotechnology firms, for whom patents are vital to obtain and retain funding. If politicians don't grasp the subject, Europe will abandon this research field to the United States and Japan. This will have harmful consequences for European public research" (Le Monde, 20 October 2011). 
These two situations show that the only alternative that scientists have is to work scientifically to go beyond the ethico-normative barrier. This is the conclusion which results from an analysis of the Brüstle affair: "This judgement is a wonderful challenge for French cellular research which, unless it turns to other, more open markets, will have to make a radical change of direction and abandon research on embryonic cells, whose economic prospects have suddenly become darker in Europe, despite the major sums that have already been invested!"13.

\section{The Extension of Stemness by iPS Cells}

Since hESCs can be used experimentally, some scientists have constantly looked for techniques that are able to satisfy the ethico-normative constraint (Pucéat, 2006). The case of the Briton Ian Wilmut, the creator of Dolly, the cloned sheep, and who chose to halt his research, is an example.

In 2007 the Japanese (Takahashi, Yamanaka, 2007) succeeded in an "induced reprogramming" on human skin cells. The technique aimed to dedifferentiate these cells by activating the expression of some genes: this is the method of induced reprogramming. It translates the fact that a specialised cell can, thanks to an action on its genome, return to a non-differentiated state. So the issues of cellular plasticity and cellular transdifferentiation are renewed through artificialisation. To do this, the technique targets the expression of four genes carrying the capacity of pluripotence, a property exclusive to hESCs. These artificialised cells are called induced pluripotent stem cells (iPS). They extend the capacity of stemness defined by lack of differentiation and infinite multiplication. Consequently, they compete with hESCs as a subject for trials, having the advantage of overcoming some obstacles that are specific to hESCs.

First, the obstacle represented by the ethico-normative barrier. Research on iPSs no longer requires a licence, because their source is a common cellular material. In fact public science policy has quickly noted this situation. This has been revealed through the proposal for tenders, which now relate to so-called pluripotent stem cells. There is no longer any connection with the embryo. From that point on, it is possible to envisage an expansion of the community of researchers. Then, from a therapeutic perspective, the iPSs remove the obstacle of the immunological barrier because, as for the CSAs, the source and the destination are the same person. But, given their production and the existing ignorance about their physiological state and

13. http://www.village-justice.com/articles/serieux-frein-recherches-cellules, $11026 . h t m l$ 
their genetic stability, scientific controversies persist. This dual significance has certainly attracted interest, which must be followed up. Let us accept the hypothesis. For its part, ISTEM is determined to develop research on iPSs, with a considered delayed effect. Because one of the criticisms developed in opposition to the use of these artificial cells for cellular therapy, at ISTEM as elsewhere, is the fluctuation in their experimental quality.

Essentially, any ethico-normative barrier against research, as here on hESCs, whatever its level of constraint, does not leave scientists inactive, politicially or scientifically. Indeed, it is through science that they partly regain control by creating a cellular artefact that is ethically harmless.

\section{CONCLUSION}

The preceding anaylsis shows that the future of research on hESCs is largely dependent on a social normativity marked by ambiguity.

First, this normativity, understood both as an engine of the dynamics of innovation and as the power to act on an ethico-normative barrier, is expressed in a low-key science policy. Describing this policy in this way comes back to considering it as the location of a strong tension which leads the State to support this research without showing it: in a hidden, limited and dispersed way. This being so, everything indicates that it is not about questioning the SIS model. We should probably see this as resulting from a political sphere that is insufficiently convinced by the scientific promises concerning hESCs to support the project. Consequently, although no public tender identifying this research has been proposed, nevertheless INSERM, through its implicit delegated role, is working on their development as part of partnerships with other institutions, in particular with the AFM.

Then this normativity has the effect of mobilising scientists, both politically and scientifically. Although, politically, they are experiencing problems in overcoming the ethico-normative barrier, they are, however, succeeding in reconfiguring their research and, in return, are changing science policy.

Essentially, even if hESCs will still be held for a long time by the embryo, paradoxically we are seeing an extension of science and technology in this field at two levels: by the mechanisms of life that they reveal and by the artificialised duplication of their own potential that they allow. It remains to be seen to what extent this extension will be a part of the SIS model. 


\section{BIBLIOGRAPHY}

BARRAL, C., PATERSON, F. (1994), L'Association française contre les myopathies: trajectoire d'une association d'usagers et construction associative d'une maladie, Sciences sociales et Santé, 12, 2.

BATEMAN NOVAES, S. (1998), La bioéthique, comme objet sociologique, Cahiers Internationaux de sociologie, CIX, 5-32.

BENNAMOUZIG, D., BESANÇON, J., (2005), Administrer un monde incertain : les nouvelles bureaucraties techniques. Le cas des agences sanitaires en France, Sociologie $d u$ travail, 47, 301-322.

BOUCHARD, J. (2008), Comment le retard vient aux français. Analyse d'un discours sur la recherche, l'innovation et la compétitivité 1940-1970, Villeneuve d'Asq, Presses Universitaires du Septentrion.

BRUNET, P. (2006), L'expert en technosciences : figure « critique » ou « gestionnaire » de la civilisation industrielle contemporaine ?, in Guespin, J., Jacq, A. (dir.), Le vivant, entre science et marché : une démocratie à inventer, Paris, Syllepse, 99-125.

BRUNET, P. (2008), Le procès de travail technoscientifique dans les biotechnologies : le cas de l'Institut des cellules souches, Rapport final, Convention DRESS-MiRe/UEVE, mai.

BRUNET, P., DUBOIS, M. (2012), Cellules souches et technoscience : sociologie de l'émergence et de la régulation d'un domaine de recherche biomédicale en France, Revue Française de Sociologie, 53-3, 391-428.

BUSH, V. (1945), Science: The Endless Frontier, Washington, US Government Printing Office.

CALLON M., RABEHARISOA, V. (1999), Le pouvoir des malades, L'Association française contre les myopathies et la Recherche, Paris, Les Presses de l'Ecole des Mines.

CASSIER, M. (2002), Brevets et éthique : les controverses sur la brevetabilité des gènes humains, Revue Française des Affaires Sociales, 3, 235-259.

DEWEY, J. (2011), La formation des valeurs, Paris, La Découverte.

FAGOT-LARGEAUlT, A. (2004), Cellules souches et clonage thérapeutique, Pour la science, 320, juin.

FOREST, J., HAMDOUCH, A. (2009), Les clusters à l'ère de la mondialisation : fondements et perspectives de recherche, Revue d'économie industrielle, 128, 9-20.

FRESSOZ, J.-B. (2012), L'apocalypse joyeuse. Une histoire du risque technologique, collection L'Univers historique, Paris, Le Seuil.

JACQ, F. (2002), Aux sources de la politique de la science : mythe ou réalités ?(1945-1970), La Revue pour l'histoire du CNRS, n6. [En ligne], mis en ligne le 5 juillet 2007. URL: http:// histoirecnrs.revues.org/document3611.html (consulté le 13 avril 2009).

JOLY, P.-B. (2016), Science réglementaire : une internationalisation divergente ? L'évaluation des biotechnologies aux États-Unis et en Europe, Revue Française de Sociologie, 57(3), 443-472.

GAUDILLIÈRE, J.-P., JOLY, P.-B., (2006), Appropriation et régulation des innovations biotechnologiques : pour une régulation transatlantique, Sociologie du travail, 48(3), 330-349.

GIBBONS, M., LIMOGES, C., NOWOTNY, E., SCHWARTZMAN, S., SCOTT, P., TROW, M. (1994), The New Production of Knowledge, London, Sage Publications. 
GRANJOU, C. (2003), L'expertise scientifique à destination politique, Cahiers internationaux de Sociologie, CXIV, 175-183.

HOTTOIS, G. (1996), Entre symboles et technosciences, Paris, Champ Vallon.

LAREDO, P., KAHANE, B. (1998), Politique de recherche et choix organisationnels de l'Association française de lutte contre la mucovicidose, Sciences Sociales et Santé, 16(3), $97-128$.

LASCOUMES, P. (1989), La formalisation juridique du risque industriel en matière de protection de l'environnement, Sociologie du travail, 3.

LEPINAY, V.-A. (2006), Les promesses des cellules souches. Scientifiques, familles et santé publique dans la controverse autour des stem cells aux USA, Sociologie du travail, 48, 350-366.

MILLS, C. W. (1967), La Suprême-Théorie, in L'imagination sociologique, Paris, François Maspero, 29-54.

OTT, M.-O. (2007), Recherche sur les cellules souches embryonnaires humaines : entre enjeux scientifiques et économiques, quel futur pour une politique globale ?, Biofutur, 273, 20-25.

PESTRE, D. (1997), La production des savoirs entre académies et marché - Une relecture historique du livre : "The New Production of Knowledge », édité par M. Gibbons, Revue d'économie industrielle, 79(1), 163-174.

PUCEAT, M. (2006), Quelles cellules souches pour la thérapie cellulaire des maladies dégénératives? Rêves et réalités biologiques, L'Observatoire de la génétique, Centre de bioéthique, IRCM, 28, juin-août.

PULMAN, B. (2005), Les enjeux du clonage - sociologie et bioéthique, Revue Française de Sociologie, 46(3), 413-442.

RABEHARISOA, V., CALLON, M. (2002), L'engagement des associations de malades dans la recherche, Revue Internationale des Sciences Sociales, 171, 65-73.

ROUBAN, L. (1990), La science et la technologie : politiques publiques, L'Année sociologique, 40.

SEVE, L. (2006), Qu'est-ce que la personne humaine? Bioéthique et démocratie, Paris, La Dispute.

STENGERS, I. (2008), Au temps des catastrophes. Résister à la barbarie qui vient, Paris, La Découverte.

TAKAHASHI, K., YAMANAKA, S. (2007), Induction of Pluripotent Stem Cells from Adult Human Fibroblasts by Defined Factors, Cell, 131(5), 861-872.

THOMSON, J. A., ITSKOVITZ-ELDOR, J., SHAPIRO, S. S., et al. (1998), «Embryonic Stem Cell Lines Derived from Human Blastocysts», Science, 282, 1145-1147.

UZUNIDIS, D. (2003), Les facteurs actuels qui font de la science une force productive au service du capital le quatrième moment de l'organisation de la production, Innovations, Cahiers d'économie de l'innovation, 17(1), 51-78. 